\title{
Deficitul izolat de hormon de creştere - cauză rară, dar tratabilă de hipostatură
}

\author{
\begin{tabular}{c} 
Raluca Maria Vlad',3, Delia Irina Nicolaescu², Alice Ioana Albu",3 \\
${ }^{1}$ Clinica Pediatrie 3, Spitalul de Urgenţă pentru Copii „Grigore Alexandrescu“, Bucureşti, România \\
2Clinica de Endocrinologie şi Diabet, Spitalul Elias, Bucureşti, România \\
${ }^{3}$ Universitatea de Medicină şi Farmacie "Carol Davila“, Bucureşti, România \\
\hline
\end{tabular}
}

\begin{abstract}
REZUMAT
Deficitul de hormon de creştere este o cauză rară de statură joasă. Recunoaşterea precoce a afecţiunii permite un tratament eficient, ducând la o talie finală cât mai apropiată de talia ţintă genetică. Prezentăm cazul unui copil în vârstă de 1 an şi 2 luni, internat în clinica noastră pentru evaluare staturo-ponderală. Pacienta fusese diagnosticată la vârsta de 1 an cu deficit de hormon de creştere într-o clinică de endocrinologie pediatrică şi a fost îndrumată în clinica noastră pentru completarea investigaţiilor şi excluderea unei patologii structurale hipotalamo-hipofizare. Investigaţiile efectuate au exclus alte cauze de statură joasă. Evaluarea imagistică a evidenţiat hipotrofie adenohipofizară cu tijă hipofizară filiformă. Se îndrumă către clinica de endocrinologie, unde se iniţiază tratament cu hormon de creştere cu evoluţie favorabilă.
\end{abstract}

Cuvinte cheie: hormon de creştere, statură joasă, hipofiză

\author{
Abrevieri \\ DGH: deficit de hormon de creştere \\ IGF-1: insulin growth factor 1 \\ IGFBP-3: insulin growth factor binding protein 3 \\ IRM: imagistică prin rezonanţă magnetică \\ GH: hormon de creştere \\ DS: deviaţii standard \\ IMC: indice de masă corporală
}

\section{INTRODUCERE}

Deficitul de hormon de creştere (DGH) este o afecţiune rară caracterizată de o secreţie inadecvată de hormon de creştere (GH) de la nivelul adenohipofizei. Prevalenţa acestei afecţiuni variază în studii între 1/3-4.000 şi 1/10.000 $(1,2)$. DGH la copil poate fi prezent de la naştere (congenital) din cauza unor mutaţii genetice sau anomalii structurale de linie mediană, dobândit în timpul vieţii în urma unor infecţii, traumatisme, tumori, intervenţii chirurgicale, iradiere sau idiopatic (3). Deficitul congenital sever de $\mathrm{GH}$ cu debut neonatal este o boală rară, dar cu potenţial de a evolua cu glicemii ameninţătoare de viaţă din prima săptămână. Abordarea practică în ceea ce priveşte diagnosticul neonatal nu este susţinută de prea multe dovezi în literatură (4). DGH poate fi izolat sau acompaniat de alte deficite hipofizare $(1,3)$.

Clinic, DGH se caracterizează prin retard al creşterii cu statură joasă şi întârziere în maturare (3). Pe lângă hipoglicemie neonatală, alte manifestări precoce pot fi micropenis sau icter prelungit cu bilirubină conjugată. Deşi talia la naştere este de obicei în limite normale, postnatal eşecul creşterii poate debuta devreme şi poate fi profund, devenind evident din primele luni de viaţă (5). Orice nounăscut/sugar cu hipoglicemii severe sau simptomatice pentru care nu există o cauză evidentă necesită testarea GH-ului din sânge. Valori sub $20 \mathrm{ng} / \mathrm{ml}$ vor 
fi sugestive pentru DGH în perioada neonatală $(5,6)$. La copiii cu retard de creştere la care s-au exclus alte cauze, valori scăzute ale IGF-1 and IGFBP-3 sunt indicative pentru DGH, mai ales la valori sub -2DS. IGF-1 este folosit frecvent ca biomarker, deşi valoarea lui se corelează slab cu obiectivele terapeutice finale în DGH. Testele de provocare pentru GH pot fi utilizate în diagnostic conform protocoalelor standardizate $(5,7,8)$. Evaluarea prin rezonanţă magnetică (IRM) a hipofizei este un element important în diagnostic. La pacienţii cu DGH congenital, IRM-ul poate evidenţia anomalii structurale precum: hipoplazie pituitară, absenţa tijei pituitare sau ectopia hipofizei posterioare. Prezenţa celei din urmă confirmă diagnosticul și este predictivă pentru deficite hipofizare multiple $(9,10)$. IRM de hipofiză este de asemenea util în a prezice evoluţia sub tratament (11).

Copilul cu statură joasă este la risc de hărţuire, imaturitate socială şi stimă de sine scăzută (12). La adult, consecinţele sunt atât de ordin psihologic (stimă de sine scăzută, depresie, anxietate), cât şi metabolice (alterarea compoziţiei corporale, osteoporoză, masă musculară scăzută, adipozitate viscerală crescută, rezistenţă la insulină, LDL-colesterol sau trigliceride crescute) $(13,14)$.

La pacienţii cu DGH, terapia cu GH este necesară precoce pentru promovarea creşterii în înălţime (15). Terapia cu somatropină umană recombinată ar trebui iniţiată imediat ce a fost stabilit diagnosticul pentru a optimiza potenţialul de creştere. Principalele obiective ale terapiei sunt: normalizarea taliei în copilărie şi atingerea potenţialului normal de creştere în înălţime în perioada de adult. Somatropina se administrează în injecţii subcutanate zilnice, în doză de $25-50 \mu \mathrm{g} / \mathrm{kg} / \mathrm{zi}$, dozele fiind adaptate în funcție de evoluţia clinică şi nivelul IGF-1. Tratamentul se întrerupe în perioada de tranziţie, când pacientul va fi evaluat pentru a se stabili necesitatea continuării terapiei în perioada de adult $(6,13,16)$.

Deşi, conform protocolului actual în România, se recomandă ca tratamentul să fie iniţiat în general după vârsta de 3 ani, în cazuri selecţionate de DGH sever congenital, întârzierea iniţierii tratamentului cu GH până la vârsta recomandată poate conduce la un deficit statural sever, dificil de recuperat ulterior şi cu posibile consecinţe psihologice la un copil, cu un important decalaj în dezvoltare comparativ cu ceilalţi copii.

\section{PREZENTARE DE CAZ}

Copil de sex feminin, în vârstă de 1 an şi 2 luni, se internează în Clinica Pediatrie 3 a Spitalului
"Grigore Alexandrescu“ pentru completarea investigaţiilor pentru hipotrofie staturo-ponderală. Din antecedentele patologice reţinem că la vârsta de 1 an a fost diagnosticată cu deficit izolat de hormon de creştere în Clinica de Endocrinologie şi Diabet a Spitalului Elias. Din antecedentele heredocolaterale reţinem sora cu deficit izolat de GH aflată în tratament cu hormon de creştere de la vârsta de 4 ani, cu răspuns bun la tratamen,t şi mama cu statură joasă severă (-3,3 DS). Copilul este în plasament de la vârsta de 3 săptămâni, având suport nutriţional şi afectiv corespunzător.

Clinic la internare, prezintă stare generală bună, facies infantil (fig. 1), statură joasă severă talie $=62$ $\mathrm{cm}(-5,6 \mathrm{DS})$, greutate $=6.000 \mathrm{~g}, \mathrm{IMC}=15,6 \mathrm{~kg} / \mathrm{m} 2$ (pc10-25), tegumente discret palide, fără pete colorate/decolorate, fără erupţii, ţesut adipos bine reprezentat preponderent troncular, echilibrată cardio-respirator, abdomen suplu, depresibil, mobil cu respiraţia, tranzit intestinal normal, micţiuni fiziologice, organe genitale externe de aspect normal, Tanner 1, fără sindrom poliuro-polidipsic, fontanela anterioară $2 / 1 \mathrm{~cm}$ normotensivă, dezvoltare psihomotorie conform vârstei cronologice.

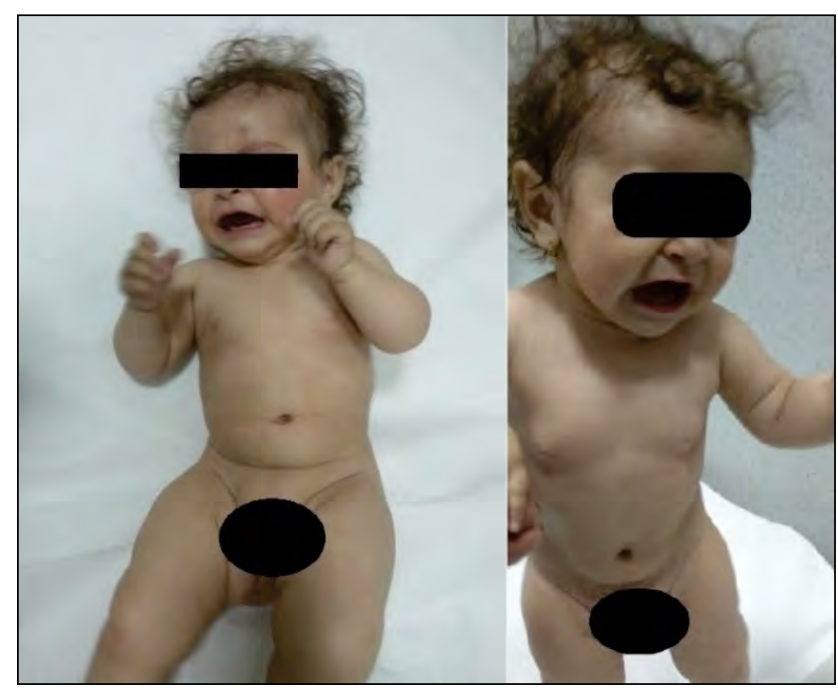

FIGURA 1. Aspectul fenotipic al pacientei (facies infantil, țesut subcutanat predominant troncular)

Paraclinic, se evidenţiază uşoară anemie hipocromă microcitară hiposideremică $(\mathrm{Hb}=10,4 \mathrm{~g} / \mathrm{dl}$; Fe seric $=31 \mu \mathrm{g} / \mathrm{dl}$ ), fără sindrom inflamator, hipercolesterolemie uşoară, fără sindrom biologic de malabsorbţie, anticorpi anti transglutaminază tisulară (tTG) $\mathrm{IgA}-1.40 \mathrm{U} / \mathrm{ml}(0-10 \mathrm{U} / \mathrm{ml})$ normali, testul sudorii $=56 \mathrm{mmol} / 1 \mathrm{NaCl}$ (valori normale), panel alergeni alimentari în limite normale. Evaluarea axului hipotalamohipofizar nu a evidenţiat alte deficite hipofizare. Investigaţiile de laborator sunt redate în tabelul 1 . 
TABELUL 1. Investigațiile de laborator ale pacientei

\begin{tabular}{|l|c|c|}
\hline Laborator & & Valori normale \\
\hline Proteine totale (g/dl) & 6,6 & $5,5-7,5$ \\
\hline Colesterol total (mg/dl) & $\mathbf{2 2 2}$ & $140-200$ \\
\hline Calciu total (mg/dl) & 10,10 & $8,4-10,2$ \\
\hline 25-OH Vitamina D (ng/ml) & 48,10 & $30-70$ \\
\hline \multicolumn{1}{|c|}{ ol (ng/ml) } & 201 & $54,94-287,56$ \\
\hline GH (ng/ml) & $\mathbf{0 , 0 5}$ & $0-8$ \\
\hline IGF-1 (ng/ml) & $\mathbf{1 5}$ & $55,00-327$ \\
\hline TSH (ulU/ml) & 5,02 & $0,7-5,97$ \\
\hline freeT4 (ng/ml) & 59,20 & $49,866-123,039$ \\
\hline Pr /ml) & 35,75 & $5-35$ \\
\hline
\end{tabular}

Radiografia de mână nondominantă (Fig. 2) a evidenţiat vârsta osoasă întârziată cu aproximativ 9 luni (conform atlasului Greulich-Pyle).

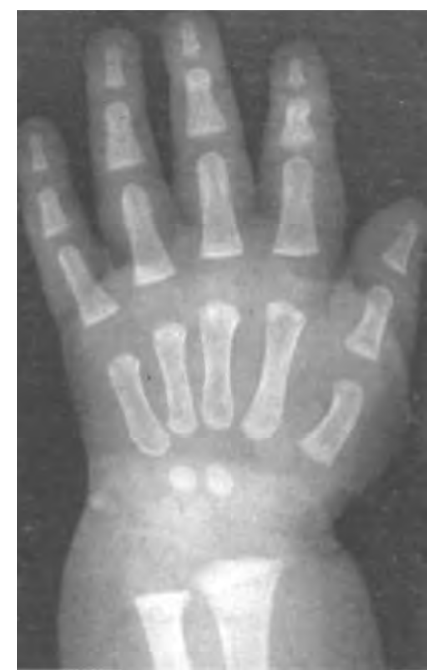

FIGURA 2. Vârsta osoasă = 6 luni

S-a efectuat IRM hipotalamo-hipofizar (conform protocolului naţional de diagnostic şi tratament cu Somatropinum), ce a evidenţiat adenohipofiză aplatizată cu dimensiuni mici 5,1/9/1,5 mm, volum $35 \mathrm{~mm}^{3}$ (volum normal pentru vârstă: $119 \pm$ $36 \mathrm{~mm}^{3}$ ) - fig. 3 şi tijă pituitară filiformă - fig. 4.
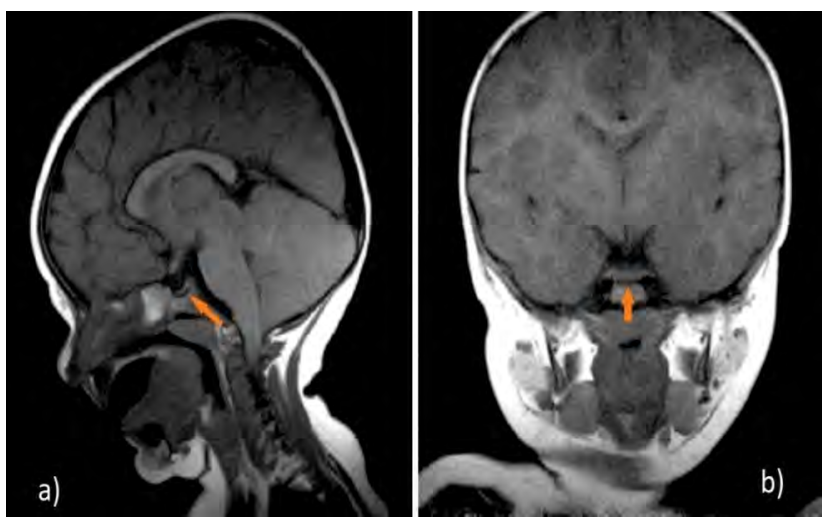

FIGURA 3. IRM hipotalamo-hipofizar: adenohipofiză cu dimensiuni mici - a) secțiune semnal T1 sagital, b) secțiune T1 coronal

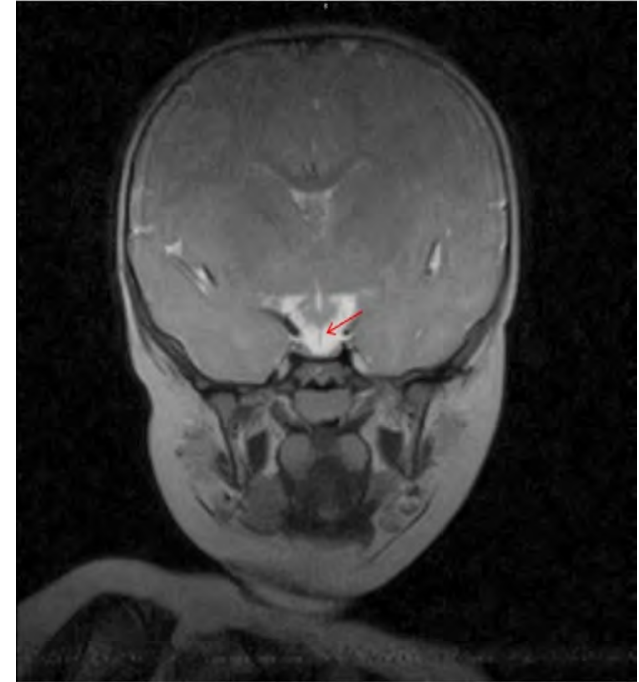

FIGURA 4. IRM hipotalamo-hipofizar (secțiune semnal T2 coronal): tijă pituitară filiformă

Investigaţiile efectuate confirmă diagnosticul de deficit izolat de GH idiopatic. Se îndrumă către Clinica de Endocrinologie, unde se iniţiază tratament cu Somatropinum $0,035 \mathrm{mg} / \mathrm{kg} / \mathrm{zi}$ subcutanat, zilnic, $7 / 7$, urmând să fie monitorizată conform protocolului în vigoare.

\section{DISCUȚII}

Statura joasă este definită ca înălţimea absolută sub 2 deviaţii standard (DS) pentru vârstă şi sex (17). Standardele antropometrice recomandate pentru înălţime sunt curbele sintetice pentru România - publicate în Acta Endocrinologica în 2016 (18). DGH este o cauză rară, dar importantă de statură joasă cu o prevalenţă de aproximativ 1:4.000 în timpul copilăriei (1). Deficitul de $\mathrm{GH}$ poate fi izolat sau în combinaţie cu alte deficite hipofizare. Diagnosticul se bazează pe combinaţia dintre particularităţile clinice (fenotip), demonstrarea deficitului de GH prin teste de provocare şi dozarea IGF-1, evaluare imagistică prin radiografie mână nondominantă şi IRM hipotalamo-hipofizar $(6,19)$.

Cazul prezentat este prototipul clasic al staturii joase prin DGH la un copil normoponderal cu istoric familial de DGH, cu statură joasă severă, armonică, IGF-1 scăzut pentru vârstă, vârstă osoasă întârziată, hipoplazie pituitară.

Cazurile familiale cu agenezie de tijă pituitară sugerează o cauză genetică (9). La pacienţii cu DGH au fost izolate mutaţii ale genei GH-1. Tsubahara et al. descriu doi fraţi cu DGH izolat născuţi din părinţi sănătoşi, neînrudiţi. Ambii au prezentat hipoglicemie neonatală, au fost diagnosticaţi în primul an de viaţă cu GHD, răspuns specific la teste de provocare, IRM normal, IGF-1 normalizat cu 
tratament, statura finală depăşeşte predicţia pentru familie. La toţi membrii familiei s-a evaluat gena GH-1. Tatăl şi ambii fraţi aveau o deleţie SNP în 5'UTR al GH-1 - rs11568827, iar mama și ambii fraţi o inversiune SNP 5' UTR al GH-1 -rs11568828. Aşadar, DGH în această familie este dat de interacţiunea a două SNP în gena GH-1, câte una moştenită de la fiecare părinte (20). Pacienta prezentată, sora ei şi, posibil, şi mama prezintă cel mai probabil DGH de cauză genetică. Nu a fost disponibilă testarea.

Literatura descrie importanţa IRM în diagnostic, această investigaţie fiind esenţială şi în cazul nostru.

Tratamentul iniţiat cât mai precoce îmbunătăţeşte prognosticul creşterii şi talia finală şi este rambursat în totalitate de Casa Naţională de Sănătate conform unui protocol standardizat (21). În cazurile severe de DGH, contracararea anomaliilor metabolice care apar ca o consecinţă a DGH este un aspect important al managementului. Având în vedere agregarea familială în cazul prezentat, imediat ce a fost stabilit diagnosticul de DGH, s-a luat decizia iniţierii terapiei în speranţa obţinerii unei talii fina- le optime. Valori semnificativ mai mari ale DS pentru talie au fost comunicate la copiii cu DGH trataţi cu somatotropină (22). Pacienţii care nu primesc terapie precoce continuă sunt la risc să nu atingă talia ţintă şi să asocieze carenţe educaţionale şi vocaţionale (23). Un beneficiu suplimentar al terapiei este îmbunătăţirea calităţii vieţii copiilor cu hipostatură (24).

\section{CONCLUZII}

Statura joasă este cea mai frecventă formă de manifestare a DGH. Poate fi cauză frecventă de prezentare la medic sau poate fi constatată de medic la momentul examinării pacientului pentru patologie neînrudită. Monitorizarea periodică a creşterii este un indicator important al sănătaţii globale şi un instrument uşor de folosit în orice cabinet medical. Medicului pediatru îi revine cel mai adesea responsabilitatea diagnosticului de hipostatură şi iniţierea algoritmului de diagnostic etiologic. În cazul DGH, un diagnostic precoce şi iniţierea rapidă a tratamentului asigură pacienţilor un prognostic excelent în ceea ce priveşte potenţialul de creştere.

Conflict of interest: none declared Financial support: none declared

\section{BIBLIOGRAFIE}

1. Stanley T. Diagnosis of growth hormone deficiency in childhood. Curr Opin Endocrinol Diabetes Obes. 2012 Feb;19(1):47-52;

2. Dattani M., Kumaran A. Growh Hormone Deficiency - Difficulties in Diagnosis and Management. Eur. Endocrinol., 2008; 4(2):90-2;

3. Bozzola M, Meazza C. Growth Hormone Deficiency: Diagnosis and Therapy in Children. In: Restricted Growth - Clinical, Genetic and Molecular Aspects. InTech; 2016.

4. Binder G, Weidenkeller M, Blumenstock G, Langkamp M, Weber K, Franz AR. Rational approach to the diagnosis of severe growth hormone deficiency in the newborn. J Clin Endocrinol Metab. 2010 May;95(5):2219-26;

5. Ogilvy-Stuart AL. Growth Hormone Deficiency (GHD) from Birth to 2 Years of Age: Diagnostic Specifics of GHD during the Early Phase of Life. Horm Res 2003;60(suppl 1):2-9

6. GH Research Society. Consensus guidelines for the diagnosis and treatment of growth hormone $(\mathrm{GH})$ deficiency in childhood and adolescence: Summary statement of the GH Research Society. J Clin Endocrinol Metab. 2000 Nov;85(11):3990-3;

7. Johannsson G, Bidlingmaier M, Biller BMKet al. Growth Hormone Research Society: Growth Hormone Research Society perspective on biomarkers of GH action in children and adults. Endocr Connect. 2018 Mar;7(3):R126-R134;

8. Ranke MB, Schweizer R, Elmlinger MW, Weber K, Binder G, Schwarze CP, Wollmann HA. Significance of basal IGF-1, IGFBP-3 and IGFBP-2 measurements in the diagnostics of short stature in children. Horm Res 2000;54:60-68;

9. Argyropoulou M, Perignon F, Brauner R, Brunelle F. Magnetic resonance imaging in the diagnosis of growth hormone deficiency. J Pediatr. 1992 Jun;120(6):886-91;

10. Bozzola M, Adamsbaum C, Biscaldi I, Zecca M, Cisternino M, Genovese E, Richard I, Kalifa G, Chaussain JL. Role of magnetic resonance imaging in the diagnosis and prognosis of growth hormone deficiency. Clin Endocrinol (Oxf). 1996 Jul;45(1):21-6;
11. Kara Ö, Esen I, Tepe D, Gülleroğlu NB, Tayfun M. Relevance of Pituitary Gland Magnetic Resonance Imaging Results with Clinical and Laboratory Findings in Growth Hormone Deficiency. Med Sci Monit. 2018 Dec 30;24:9473-8;

12. Cohen $P$, Rogol AD, Deal $C L$ et al. Consensus Statement on the Diagnosis and Treatment of Children with Idiopathic Short Stature: A Summary of the Growth Hormone Research Society, the Lawson Wilkins Pediatric Endocrine Society, and the European Society for Paediatric Endocrinology Workshop. J Clin Endocrinol Metab. 2008, 93, 4210-4217;

13. Snyder P, Cooper D, Martin Kathrin A. Growth hormone deficiency in adults - UpToDate (https://www.uptodate.com/contents/growthhormone-deficiency-in-adults);

14. Bradley S. Miller. Growth Hormone Deficiency (www. magicfoundation.org/);

15. Wit JM, van Unen H. Growth of infants with neonatal growth hormone deficiency. Arch Dis Child. 1992 Jul;67(7):920-4;

16. Head J, Levy R.A. Growth Hormone Deficiency. NORD National Organisation for Rare Disorders (https://rarediseases.org/rarediseases/growth-hormone-deficiency/);

17. Rogol A, Snyder P, Hoppin A. Causes of short stature - UpToDate (https://www.uptodate.com/contents/causes-of-short-stature).

18. Pascanu I, Pop R., Barbu CG et al. Development of Synthetic Growth

19. Pedicelli S, Peschiaroli E, Violi E, Cianfarani S. Controversies in the definition and treatment of idiopathic short stature. J Clin Res Pediatr Endocrinol. 2009;1(3):105-15;

20. Tsubahara M, Hayashi Y, Niijima S, Yamamoto M, Kamijo T, Murata Y, Haruna H, Okumura A, Shimizu T. Isolated growth hormone deficiency in two siblings because of paternal mosaicism for a mutation in the GH1 gene. Clin Endocrinol (Oxf). 2012 Mar;76(3):420-4;

21. Lista protocoalelor terapeutice aprobate prin Ordinul MS/CNAS nr. 1301/500/2008 cu modificarile si completarile ulterioare (www.cnas.ro). Charts for Romanian Population. Acta Endocrinol. 2016;12(3):309-18; 
22. Takeda A, Cooper K, Bird A, Baxter L, Frampton GK, Gospodarevskaya E, Welch K, Bryant J. Recombinant human growth hormone for the treatment of growth disorders in children: a systematic review and economic evaluation. Health Technol Assess. 2010 Sep;14(42):1-209;

23. Ben-Nun Yaari E, Kauli R, Lilos P, Laron Z. Health and Lifestyle of Adult Patients with Congenital Isolated Growth Hormone Deficiency Treated in Childhood. Isr Med Assoc J. 2019 Mar;21(3):189-193;
24. Butler G, Turlejski T, Wales G, Bailey L, Wright N. Growth hormone treatment and health-related quality of life in children and adolescents: A national, prospective, one-year controlled study. Clin Endocrinol (Oxf). 2019 May 11. (Epub ahead of print). 